\title{
CALCULATION OF WETLANDS ECOLOGICAL WATER REQUIREMENT IN CHINA'S WESTERN JILIN PROVINCE BASED ON REGIONALIZATION AND GRADATION TECHNIQUES
}

\author{
ZHANG, L. ${ }^{1}-$ HOU, G. L. ${ }^{1}-$ ZHANG, G. X. ${ }^{1 *}-$ LIU, Z. L. ${ }^{1}-$ SUN, G. Z. ${ }^{1,2}-$ LI, M. N. ${ }^{3}$ \\ ${ }^{I}$ Northeast Institute of Geography and Agroecology, Chinese Academy of Sciences, Changchun, \\ 130102, P. R. China \\ ${ }^{2}$ School of Engineering, Edith Cowan University, Joondalup, WA 6027, Australia \\ ${ }^{3}$ JILIN Province Water Resource and Hydropower Consultative Company, Changchun, \\ 130026,P.R. China \\ *Corresponding author \\ e-mail:zhgx@iga.ac.cn \\ (phone:+86-431-85542210; fax:+86-431-85542298) \\ (Received $16^{\text {th }}$ Nov 2015; accepted $25^{\text {th }}$ Apr 2016)
}

\begin{abstract}
In this study a method for measuring the regional hydrological connectivity and water supply requirement of wetlands in Western Jilin Province (WJL) is defined and verified. The ecological water requirements of 216 wetlands, under various guarantee frequencies, were calculated and analyzed. In addition, twelve indicators were used to establish an evaluation index system, to characterize their ecological water requirements. The results showed that 12 hydrologically connected regions were delineated in WJL, and the 216 wetlands can be classified to six grades by AHP (Analytic Hierarchy Process) method. The annual minimum, suitable, and maximum ecological water requirements of these wetlands were found to be $7.72 \times 10^{8} \mathrm{~m}^{3}, 13.76 \times 10^{8} \mathrm{~m}^{3}, 26.15 \times 10^{8} \mathrm{~m}^{3}$ respectively, with $50 \%$ guarantee frequency. The primary water supply to the lakes and marshes was found to be from regional sources that provided a scientific basis for the allocation of water resources from the interconnected river-lake system network (IRLSN) in WJL.
\end{abstract}

Keywords: Western Jilin Province, hydrological connectivity regionalization, AHP, ecological water demand.

\section{Introduction}

Western Jilin Province (WJL) is located in the hinterland of Songnen Plain, an ecological fragile region in the transitional zone from semi-humid to semi-arid climate. The region has the largest, and one of the most important, wetland ecosystems in Songhua River Basin (Pan et al., 2006; Ren et al., 2007). At present, maintaining the ecological health of these wetlands is hampered by insufficient knowledge of their water supply requirements.

Geographically, the WJL region is flat and situated mainly on an alluvial plain, making the discharge of surface waters into the region difficult. In recent decades, the influence of climate change (rising temperatures and declining rainfall) and human activities 
(engineered hydraulic structures, such as reservoir) have weakened and damaged existing river-lake connection networks, causing a sharp decline of streamflows into two major rivers in the region, Huolin River and Tao'er River. As a result, the wetlands are showing clear signs of deteriorating ecological functions and acreage losses (Yue et al., 2008).

The amount of river water flowing across WJL (in particular, Nenjiang River, Songhua River) is still abundant for sustaining agricultural activities and wetland ecosystem, if the water resource is appropriately connected and allocated. A large-scale water management scheme, namely "Interconnected River-Lake System Network" (IRLSN), is being planned in WJL. It aims to coordinate the use of various water resources, to replenish lakes of significant ecological or economic values, provide water storage, and restore some ecologically important natural wetlands, such as Xianghia, Momoge, Chagan Lake Nature Reserve Wetlands (Dong et al., 2014). The IRLSN must be guided by a scientific approach of analyzing water supply-demand relation in hydrologically connected or separated regions, as it would be reckless to link waterways and storages without careful research and design.

Hydrology regime is the driving force behind the formation of wetlands (Zhang et al., 2014). Hydrological connectivity is the basis of water supply and allocation; it should be the first to be analyzed in quantitative studies of how waterways in neighboring regions can be connected in water management. Bracken et al. (2013) classified the research around hydrological connectivity into five broad themes based on: i) soil moisture; ii) flow processes; iii) terrain; iv) models; and v) indices. This classification yielded a definition of hydrological connectivity, and laid a foundation of conceptualization and methodology of different research approaches. Many researchers studied regional water resources based on hydrology, bio-ecology, nutrient migration and material deposited (Freeman et al., 2007; Lexartza-Artza and Wainwright, 2009; Lesschen et al., 2009; Luo et al., 2011; Shore et al., 2013). The boundary of their studies were individual catchments, as it is relatively easier to carry out research on a single catchment compared with studies on a vast region with numerous rivers, scattered lakes and marsh wetlands. In China, studies on hydrological connections need to be based on functional structures of regional water network, with evaluation standards and methods that suit the regional conditions (Zang et al., 2014; Li et al., 2014); such approach is used in this study.

After studying hydrological connectivity, the evaluation of water requirement of wetlands needs to be carried out, for protecting and restoring different wetlands and meeting their ecological water requirement according, especially when managed flood is the main source of water connection. While the method of calculating wetland ecological water requirement is well known ( $\mathrm{Li}$ et al., 2009), only limited studies have been carried out on the wetland water requirement for sustaining ecological functions. Zhang et al. (2013) used the Analytic Hierarchy Process (AHP) approach to determine weighted indices of different factors that affect wetland ecosystem values, incorporating environmental constraints and socio-economic value in each index (Wang et al., 2003; Herath, 2004). Jiang and Lee (2013) proposed a method to simplify the selection of 
wetlands for priority management. Four types of evaluation categories were proposed: areas with a high value for the conservation of the ecosystem; areas with a high potential impact on biodiversity; wetland size; and eco-networks. Then, the overall wetland water requirement was classified via an overlay analysis performed using the analytical results for each evaluation indicator. These previously studies divided the wetlands in WJL to Class 1 and 2 wetlands.

The objectives of this study are to: (1) determine the water supply domain of wetlands in WJL through hydrological connection analyses, (2) establish a more refined grading system of wetland water requirements, using AHP method, and (3) calculate the ecological water requirements of wetlands under different guarantee frequencies. In addition, this study aims to contribute to formulating water resource management strategies for wetland eco-system protection and flood management in the IRLSN scheme.

\section{Materials and Methods}

\section{Study Area}

Located between $43^{\circ} 22^{\prime} \mathrm{N}-46^{\circ} 18^{\prime} \mathrm{N}$ and $121^{\circ} 36^{\prime} \mathrm{E}-126^{\circ} 12^{\prime} \mathrm{E}$, Western Jilin has an area of $55,340 \mathrm{~km}^{2}$ that consists of 11 counties (cities): Baicheng, Zhenlai, Taonan, Tongyu, Daan, Songyuan, Qianguo, Qian'an, Changling, Fuyu, Nong'an (Figure 1). It is the transitional zone between arid climate in inner-Mongolia and semi-humid in Eastern Jilin. Based on data collected from 20 meteorological stations in WJL, the mean annual rainfall during 1975-2010 was $350-500 \mathrm{~mm}$, while the temperature ranged -30 to $-2{ }^{\circ} \mathrm{C}$ in January and 12 to $33{ }^{\circ} \mathrm{C}$ in July (Li et al., 2015).

Major rivers merging in WJL include Tao'er River, Huolin River. Major rivers crossing WJL include Nenjiang River and the Second Songhua River. As illustrated in Figure 1, Nenjiang River is located in northern border of WJL, the Second Songhua River is located in the northeast border, Tao'er River in western WJL, and Huolin River (in central WJL) are tributaries of Nenjiang River.

According to survey data, the total area of natural wetlands in WJL decreased 1100 $\mathrm{km}^{2}$ from 1980 to 2002 . The current area of wetlands is only $22 \%$ of the original size (Li, 2011). Three major objectives of IRLSN scheme include: (a) effectively utilizing the flood waters of Songhua River, Nenjiang River, Tao'er River and Huolin River to connect the main wetlands, lakes, ponds and reservoirs in the region, (b) building four core ecological plates on Xianghai, Momoge, Chagan and Boluo Lake, and (c) through effective management of flood water, improving the existing, or creating new, ecological communities in Xianghai, Momoge, Chagan and Boluo Lake areas (Jilin Daily, 2015). As such, the existing 216 wetlands were selected as the main research objects in this study. 


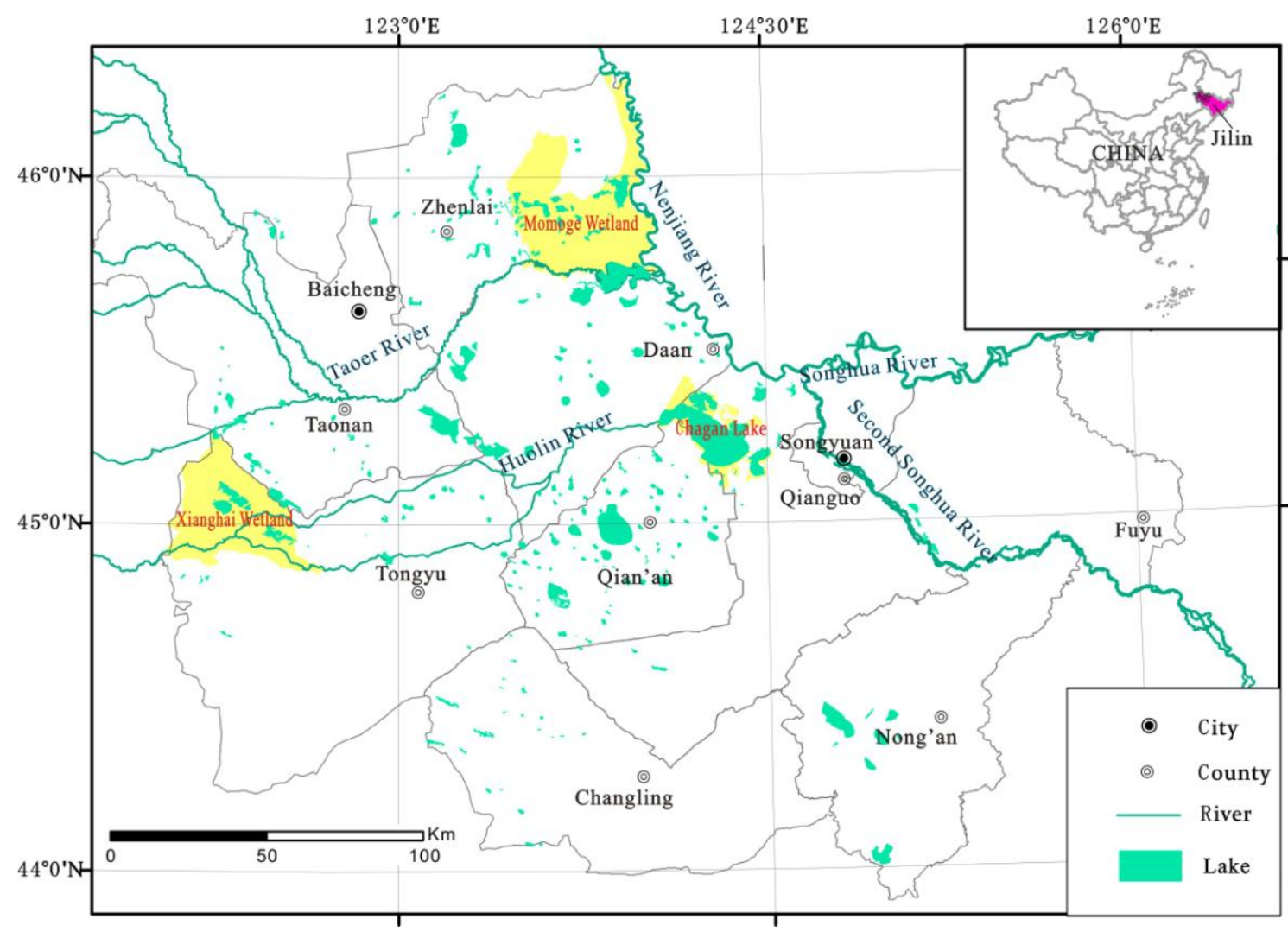

Figure 1. Distribution of wetlands in Western Jilin province

\section{Hydrological connectivity analysis}

Flood inundation method for analyzing the hydrological connectivity of lakes in WJL

Some flood waters are considered water resources in the IRLSN scheme. A source-flood method (Wang et al., 2010) can be used for flood inundation analysis. In this study, when flood level $(\mathrm{H})$ is given, the flood inundation area has been calculated by seed filling algorithm used in a previous study (Wang et al., 2010), as follows:

a) With known starting grid unit (grid unit with dike break position) and flood level $(\mathrm{H})$, initial a queue structure, add starting grid unit to the queue;

b) Pop first element (grid unit) of the queue, check "up, down, left, right" four nearby grid units in DEM, if grid unit elevation is lower than flood level $(\mathrm{H})$, then add this grid unit to the queue;

c) If the queue is not null, go to step 2, else go to step 4;

d) Output queue, all grid units in queue compose the submerged area.

\section{Watershed delineation method}

Watershed delineation is one of the most commonly performed activities in hydrological analyses. Digital elevation models (DEMs) provide good terrain representation, from which watersheds can be derived automatically using GIS 
technology. In this study 1:50000 scale DEM was used for watershed delineation, followed by merging sub-watersheds in WJL according to different water supply resources; allowing different regional hydrological connectivity to be determined.

\section{Grading of wetland water supply requirements by AHP method}

The Analytic Hierarchy Process (AHP) (Saaty, 1980) was used to establish the indexed grading system for wetlands. The procedure of using the AHP method, as described by Wang et al. (2003), included: (a) establishing the index system; (b) constructing the judgment matrix and single permutation of layer; (c) sequencing the at layers; and (d) drading of single element and comprehensive evaluation. Then the natural breaks classification method in the Arcgis technique was used to assign the grades of water supply requirements of the wetlands.

In WJL, the calculation range of wetland ecological water requirement was the wetland in different hydrological connectivity and grading regions. The sum of ecological water requirement of lake, reservoir, and other open water and water requirement of marsh wetland is shown below:

$$
\mathrm{D}=\sum \mathrm{A}_{\mathrm{i}}\left(\mathrm{ET}_{\mathrm{i}}-\mathrm{P}\right) \times 10^{-3}
$$

Where: D represents ecological water requirement $\left(\mathrm{m}^{3}\right) ; \mathrm{A}_{\mathrm{i}}$ is the area of each part $\left(\mathrm{m}^{2}\right)$; $\mathrm{ET}_{\mathrm{i}}$ represents the evapotranspiration of each part $(\mathrm{mm})$; and $\mathrm{P}$ represents the precipitation of each part (mm).

\section{Results and Discussion}

\section{The hydrological connectivity regionalization}

Considering different sources of water supply, and combining flood inundation analysis with subwatershed delineation results, the regions that are hydrologically connected have been identified, as shown in Figure 2. Flood waters that generated flow into the 216 wetlands in WJL has also been identified (Table 1).

The flood water from Nenjiang River artesian flow connected region, Tao'er River artesian flow connected region, Huolin River artesian flow connected region and Second Songhua River artesian flow connected region were found to be Nenjiang River, Tao'er River, Huolin River and Second Songhua River, respectively. Additionally, the water levels corresponding to each of these water supply sources were $131 \mathrm{~m}, 141.2$ to $221.6 \mathrm{~m}, 152 \mathrm{~m}$, and $175 \mathrm{~m}$, respectively. In addition to flood waters, water sources to the wetland included water diversion from Nenjiang River to Baicheng, and water diversion from Tao'er River to Xianghai and Hadashan hydro junction. The water diversion project from Nenjiang River to Baicheng was dependant on water lifting, and 
the water level of the main channel needed to reach $133 \mathrm{~m}$, which could artesianly flow into the channel artesian flow connected region. The function of Yangshapao reservoir was to store the water in the project, and the normal impounded water level was $135.2 \mathrm{~m}$. So, $135.2 \mathrm{~m}$ was considered as a threshold of artesian flow, and through the flood inundation analysis, the water level for water lifting was $141 \mathrm{~m}$. For water diversion project from Tao'er River to Xianghai, when the water level reached $175.4 \mathrm{~m}$, the water artesianly supplied the channel artesian connected region. Chuangye resorvoir, used to store water, is located at high geographical position; its water level of $163 \mathrm{~m}$ artesianly supplied the lakes in its waterhsed. At Hadashan hydro junction, water was diverted from Tao'er River to Huaaopao Lake, and the normal diversion water level was $141 \mathrm{~m}$. The normal water level of Huaaopao was $139 \mathrm{~m}$, which was also considered as a threshold of artesian flow. When the water lifting level reached $154 \mathrm{~m}$, the water supplied Huaaopao Lake lifting the connected region.

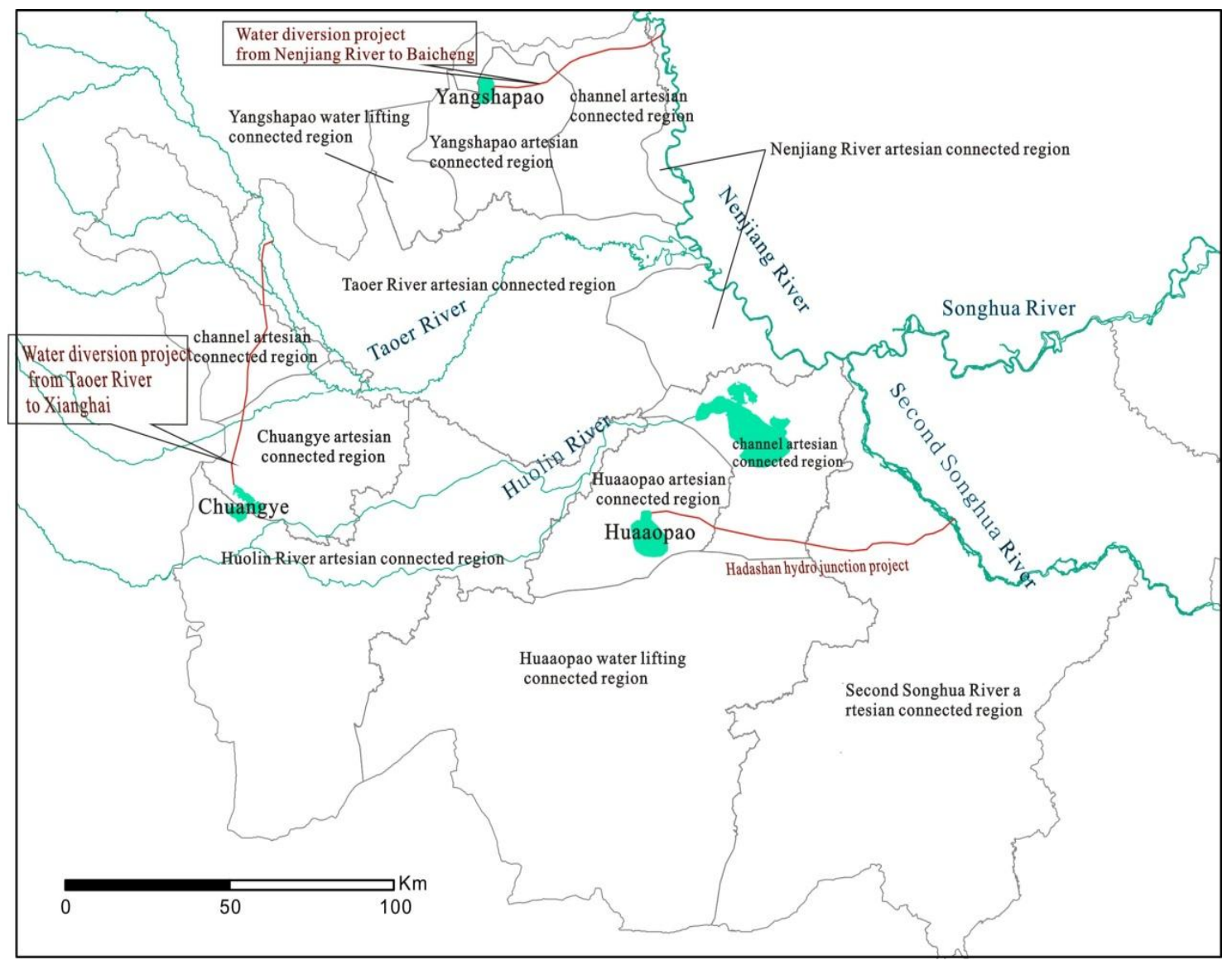

Figure 2. Hydrological connected regions in WJL 
Table1. Water level of different water supply sources for hydrological connected regions

\begin{tabular}{|c|c|c|}
\hline \multicolumn{2}{|c|}{ Name of hydrological connected regions } & $\begin{array}{l}\text { Water level elevation } \\
\text { as source of supply } \\
\text { (m) }\end{array}$ \\
\hline \multicolumn{2}{|c|}{ Nenjiang River artesian connected region } & 131 \\
\hline \multicolumn{2}{|l|}{ Tao'er River artesian connected region } & $\begin{array}{l}\text { downstream,141.2; } \\
\text { upsream, 221.6 }\end{array}$ \\
\hline \multicolumn{2}{|l|}{ Huolin River artesian connected region } & 152 \\
\hline \multicolumn{2}{|c|}{ Second Songhua River artesian connected region } & 175 \\
\hline \multirow{3}{*}{$\begin{array}{l}\text { Water diversion project from } \\
\text { Nenjiang River to Baicheng (NB) } \\
\text { connected region }\end{array}$} & NB channel artesian connected region & 133 \\
\hline & $\begin{array}{l}\text { Yangshapao Reservoir artesian } \\
\text { connected region }\end{array}$ & 135.2 \\
\hline & $\begin{array}{l}\text { Yangshapao Reservoir water lifting } \\
\text { connected region }\end{array}$ & 141 \\
\hline \multirow{5}{*}{$\begin{array}{l}\text { Water diversion project from } \\
\text { Tao'er River to Xianghai (TX) } \\
\text { connected region } \\
\text { Hadashan hydro junction (HD) } \\
\text { connected region }\end{array}$} & TX channel artesian connected region & 175.4 \\
\hline & $\begin{array}{l}\text { Chuangye Reservoir artesian } \\
\text { connected region }\end{array}$ & 163 \\
\hline & $\begin{array}{l}\text { HD channel artesian flow connected } \\
\text { region }\end{array}$ & 129 \\
\hline & $\begin{array}{l}\text { Huaaopao Lake artesian connected } \\
\text { region }\end{array}$ & 139 \\
\hline & $\begin{array}{l}\text { Huaaopao Lake lifting connected } \\
\text { region }\end{array}$ & 154 \\
\hline
\end{tabular}

\section{Grading of water supply requirements by wetlands}

\section{Indices for evaluating}

The establishment of the evaluation index system was the key of AHP. Combining the hydro-geomorphology, ecological characteristics and function, and influence of human activities, a grading system was derived to signify water supply requirements by the wetlands in WJL (Table 2).

Table 2. Indexes for evaluating water supply grading for wetlands

\begin{tabular}{lll}
\hline Target hierarchy & Criteria hierarchy & Indices hierarchy \\
\hline \multicolumn{2}{l}{$\begin{array}{l}\text { Grading of water supply } \\
\text { requirements }\end{array}$ Hydro-geomorphology (C1) } & The type of water source (P1) \\
wetlands in WJL (A) & & Distance to water source (P2) \\
& & Geomorphic conditions (P3) \\
& \multirow{2}{*}{ Wetlands' characteristics (C2) } & Relative altitude to water source (P4) \\
& & Normal storage capacity (P5)
\end{tabular}




$\begin{array}{ll} & \text { Normal storage level (P6) } \\ & \text { water surface area (P7) } \\ \text { Wetlands' function (C3) } & \text { regulation capacity of flood (P8) } \\ & \text { Water supply capacity (P9) } \\ & \text { Matter production capacity (P10) } \\ \text { Influence of human activities (C4) } & \text { Distance to residential area (P11) } \\ & \text { Distance to farmland (P12) }\end{array}$

Scheme of AHP weighting for the indices

After establishing the evaluation index system, the relations among various layers and factors were placed in comparing matrixes that had the ratios of comparative importance of paired factors. Then, the values of the relative weight were calculated. Finally, Matlab was used to calculate the weight of each index according to AHP; resuls shown in Table 3.

Table 3. Weights Scheme for each index

\begin{tabular}{ll}
\hline Weight of Ci & Weight of Pi \\
\hline (C1) 0.564 & (P1) 0.3265 \\
& (P2) 0.0897 \\
& (P3) 0.1162 \\
& (P4) 0.0316 \\
& (P5) 0.1086 \\
& (P6) 0.0684 \\
& (P7) 0.0860 \\
(C3) 0.118 & (P8) 0.0648 \\
& (P9) 0.0284 \\
& (P10) 0.0248 \\
(C4) 0.055 & (P11) 0.0275 \\
& (P12) 0.0275 \\
\hline
\end{tabular}

Grading of water supply requirements of wetlands

Using the comprehensive evaluation method, the composite index of each wetland was calculated. The natural breaks classification method in the Arcgis technique was used to finally determine the water supply grading for wetlands; results shown in Figure 3. 


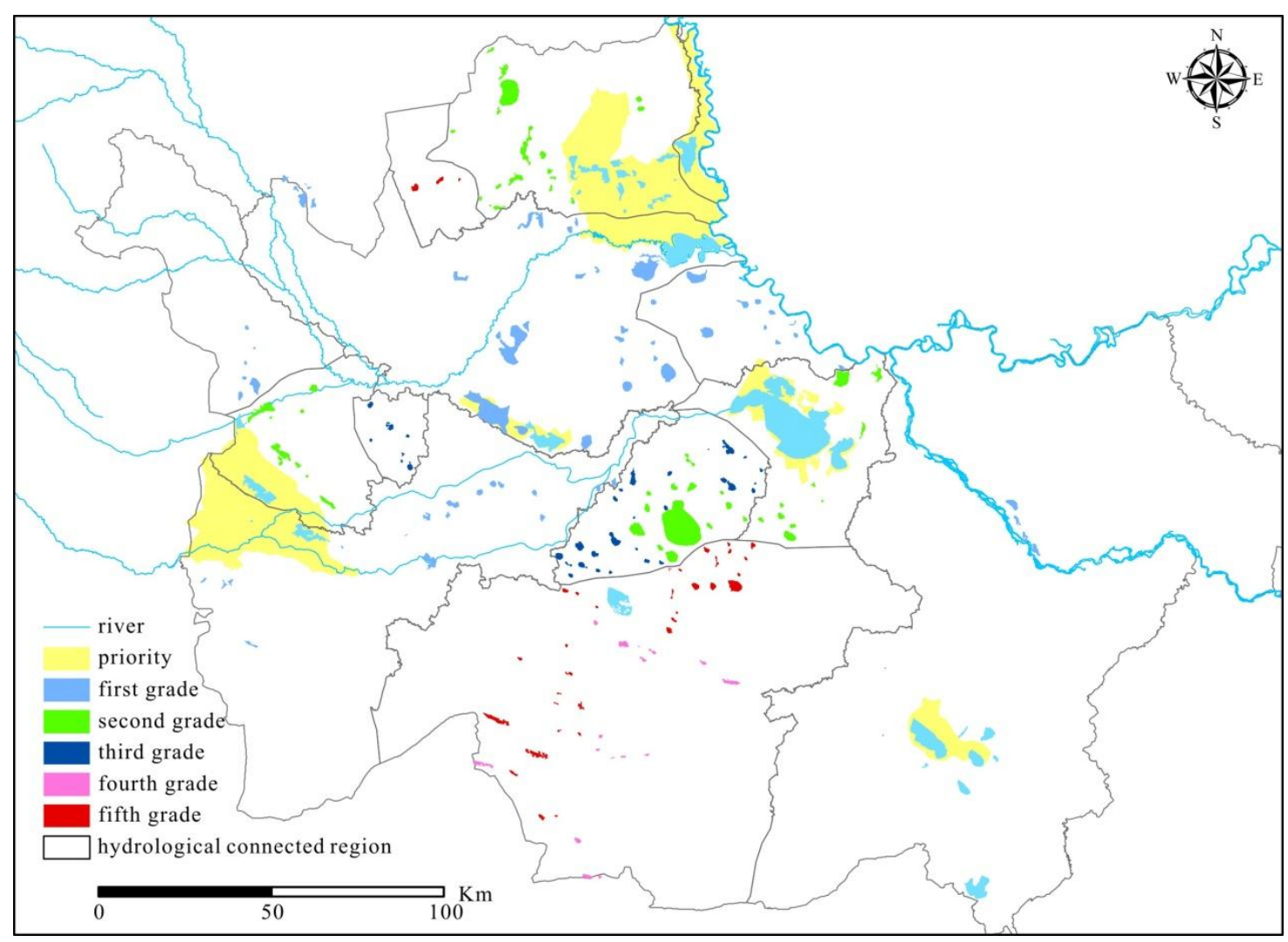

Figure 3. Water supply grading for wetlands in WJL

According to the grading results in Figure 3, the national or provincial wetland nature reserve (Chagan Wetland, Momoge Wetland, Xianghai Wetland, Niuxintaobao Wetland, Dabusu Wetland and Boluo Wetland) should be prioirities for water supply in the IRLSN scheme. The first grade lakes were mainly near the river. The second and third grade lakes were mostly located near the Water diversion projects. The fourth and fifth grade lakes were at the south of WJL, where the water source was primarily rainfall and surface runoff.

\section{Regionalization and Grade Calculation of Wetlands Ecological Water requirement in WJL}

According to the regionalization and grading result, the corresponding ecological water requirement of wetlands was calculated. The ecological water requirements of Chagan Wetland, Momoge Wetland, Xianghai Wetland(national natural wetlands), and Niuxintaobao Wetland, Dabusu Wetland and Boluo Wetland (provincial nature reserves), were found to have the minimum ecological water requirements in WJL. The ecological water requirements of rest open water of lakes, ponds, reservoirs and adjacent marsh wetlands extracted from 2012 landuse map (Figure 4) were considered as suitable ecological water requirement in WJL. The maximum ecological water requirements were 
the sum of suitable ecological water requirements and the ecological water requirements of adjacent marsh wetlands extracted from 1950s landuse map (Figure 4), and the adjacent mash wetlands were only the the area of marsh wetlands (in 1950s' landuse map) that were converted to saline-alkali soil lands in 2012 landuse map (Figure 4).

Through the statictical analysis of monthly precipitation and evaporation from 1960 to 2014 in 10 counties (cities), the monthly precipitation and evaporation under $25 \%, 50 \%$, $75 \%$, and $90 \%$ guarantee rate in each counties (cities) were determined. Sheng et al. (2007) found that the conversion coefficient between evaporation measured by a small evaporation pan and water surface evaporation was 0.5-0.6. In this study, the conversion coefficient was found to be 0.6 . In marsh wetlands, the main vegetation was found to be Phragmites that typically grow between April and September in WJL. Thus, the ecological water requirement of marsh wetlands were only calculated between April and September. The evaporation was calculated by the 2.5 times of water surface evaporation from June to August, and 1.3 times in April, May and September (Tang et al., 2005). The ecological water requirement of lakes and marshes in each region and grading calculated in this study are shown in Tables 4, 5 and 6.

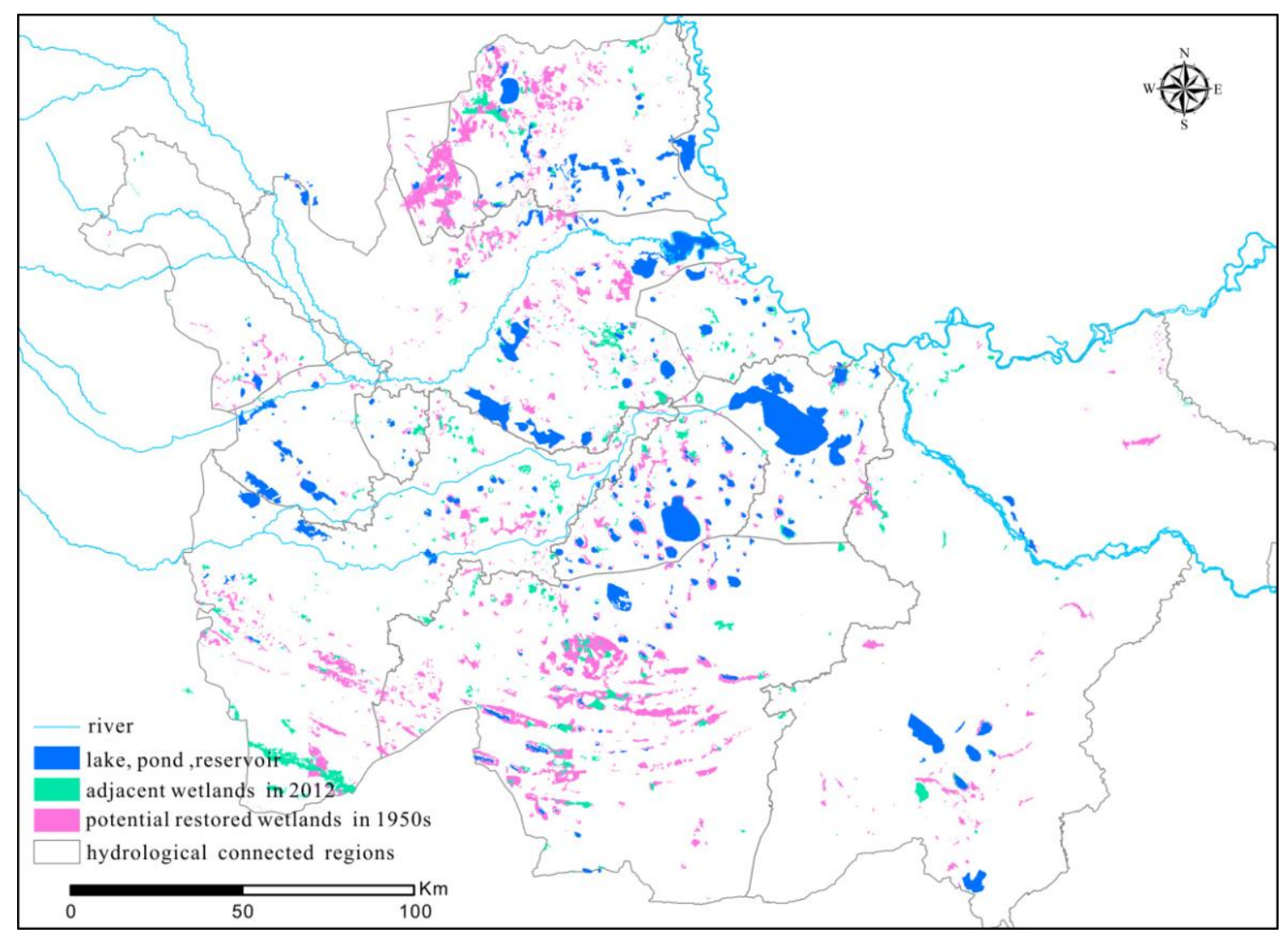

Figure 4. Distribution of existing and potential restoring wetlands of WJL 
Table 4. Minimum ecological water requirements in WJL

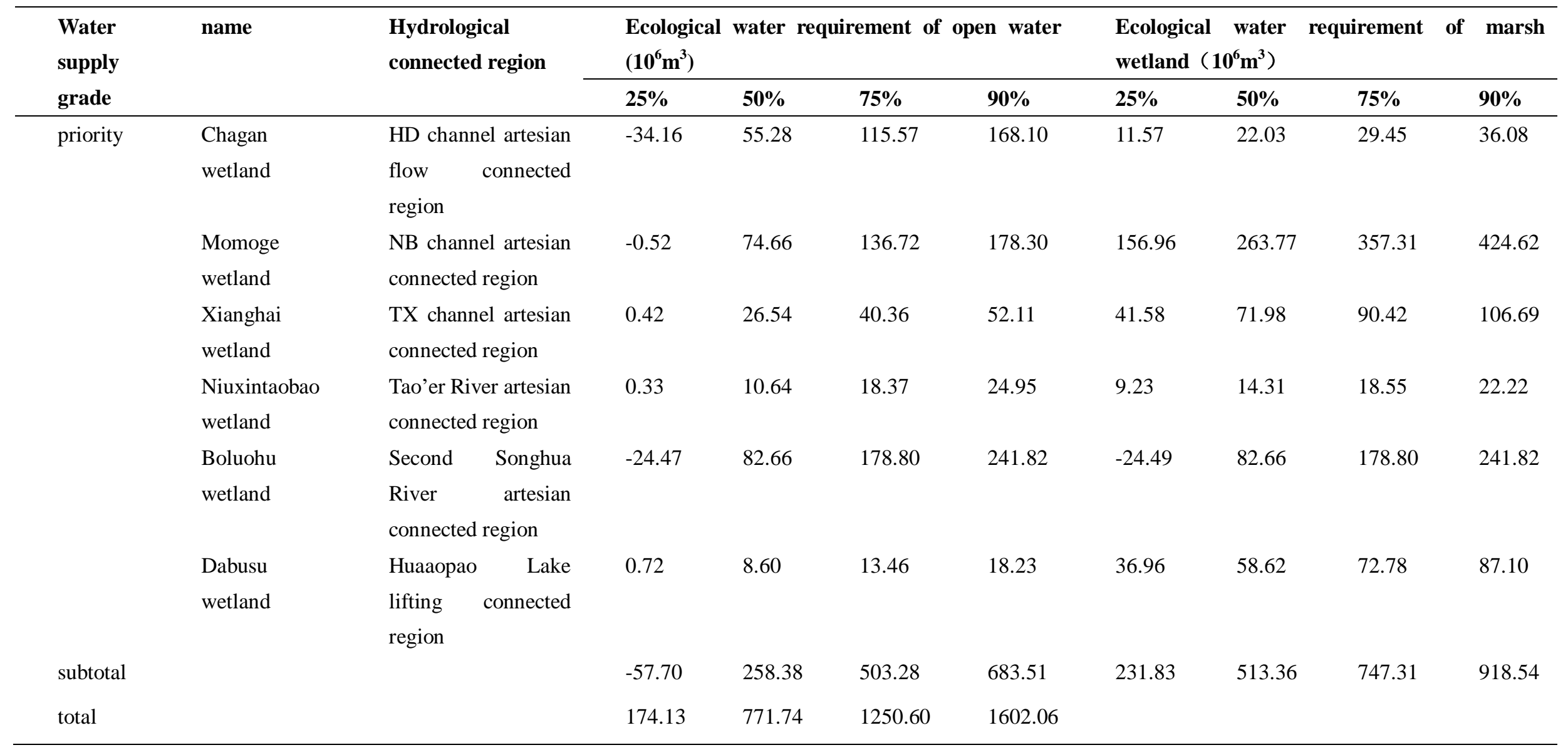


Table 5. Suitable ecological water requirement in WJL

\begin{tabular}{|c|c|c|c|c|c|c|c|c|c|}
\hline \multirow[t]{2}{*}{$\begin{array}{l}\text { Water } \\
\text { grade }\end{array}$} & \multirow[t]{2}{*}{ Hydrological connected region } & \multicolumn{4}{|c|}{$\begin{array}{l}\text { Ecological water requirement of open water } \\
\left(10^{6} \mathrm{~m}^{3}\right)\end{array}$} & \multicolumn{4}{|c|}{$\begin{array}{l}\text { Ecological water requirement of marsh wetland } \\
\left(10^{6} \mathrm{~m}^{3}\right)\end{array}$} \\
\hline & & $25 \%$ & $50 \%$ & $75 \%$ & $90 \%$ & $25 \%$ & $\mathbf{5 0 \%}$ & $75 \%$ & $90 \%$ \\
\hline \multirow[t]{4}{*}{ first } & Nenjiang River artesian connected region & 0.26 & 1.19 & 20.73 & 28.20 & 11.43 & 19.20 & 26.01 & 30.92 \\
\hline & $\begin{array}{l}\text { Second Songhua River artesian connected } \\
\text { region }\end{array}$ & -6.13 & 2.46 & 10.95 & 16.49 & 17.70 & 34.66 & 47.54 & 60.03 \\
\hline & Tao'er River artesian connected region & 10.73 & 64.74 & 104.42 & 137.49 & 41.13 & 66.38 & 86.36 & 102.41 \\
\hline & Huolin River artesian connected region & 0.20 & 12.19 & 18.71 & 24.25 & 73.00 & 126.38 & 158.74 & 187.32 \\
\hline \multirow[t]{4}{*}{ second } & $\begin{array}{l}\text { Yangshapao Reservoir artesian connected } \\
\text { region }\end{array}$ & -0.15 & 21.79 & 39.90 & 52.03 & 23.45 & 39.41 & 53.39 & 63.45 \\
\hline & $\begin{array}{l}\text { Chuangye Reservoir artesian connected } \\
\text { region }\end{array}$ & 2.85 & 9.41 & 13.88 & 17.84 & 2.56 & 4.43 & 5.56 & 6.56 \\
\hline & Huaaopao Lake artesian connected region & -1.43 & 19.59 & 31.07 & 41.98 & 14.16 & 22.46 & 27.89 & 33.37 \\
\hline & HD channel artesian flow connected region & -0.89 & 9.77 & 16.58 & 22.97 & 9.61 & 18.28 & 24.44 & 29.95 \\
\hline \multirow[t]{2}{*}{ third } & Huaaopao Lake artesian connected region & -0.95 & 13.06 & 20.71 & 27.99 & 9.44 & 14.98 & 18.59 & 22.25 \\
\hline & $\begin{array}{l}\text { Chuangye Reservoir artesian connected } \\
\text { region }\end{array}$ & 1.48 & 4.76 & 7.01 & 9.01 & 3.92 & 6.78 & 8.52 & 10.08 \\
\hline fourth & Huaaopao Lake lifting connected region & -2.17 & 16.08 & 29.49 & 40.21 & 24.63 & 41.16 & 57.02 & 68.22 \\
\hline \multirow[t]{2}{*}{ fifth } & Huaaopao Lake lifting connected region & -1.17 & 8.66 & 15.88 & 21.65 & 13.26 & 22.16 & 30.70 & 36.74 \\
\hline & $\begin{array}{l}\text { Yangshapao Reservoir water lifting } \\
\text { connected region }\end{array}$ & -0.01 & 1.85 & 3.39 & 4.42 & 1.23 & 2.08 & 2.81 & 3.34 \\
\hline \multicolumn{2}{|l|}{ subtotal } & 2.62 & 185.57 & 332.74 & 444.53 & 245.53 & 418.38 & 547.60 & 654.63 \\
\hline \multicolumn{2}{|l|}{ total } & 248.16 & 603.95 & 880.34 & 1099.16 & & & & \\
\hline \multicolumn{2}{|c|}{ Minimum ecological water requirement } & 174.13 & 771.74 & 1250.60 & 1602.06 & & & & \\
\hline \multicolumn{2}{|c|}{ Suitable ecological water requirement } & 422.29 & 1375.69 & 2130.94 & 2701.22 & & & & \\
\hline
\end{tabular}


Table 6. Maximum ecological water requirement in WJL

\begin{tabular}{|c|c|c|c|c|c|}
\hline \multirow[t]{2}{*}{ Water supply grade } & \multirow[t]{2}{*}{ Hydrological connected region } & \multicolumn{4}{|c|}{ Ecological water requirement of marsh wetland $\left(10^{6} \mathrm{~m}^{3}\right)$} \\
\hline & & $25 \%$ & $\mathbf{5 0 \%}$ & $75 \%$ & $90 \%$ \\
\hline \multirow[t]{6}{*}{ priority } & Chagan wetland & 0 & 0 & 0 & 0 \\
\hline & Momoge wetland & 47.45 & 82.08 & 103.10 & 121.67 \\
\hline & Xianghai wetland & 253.60 & 0.42 & 26.54 & 40.36 \\
\hline & Niuxintaobao wetland & 15.59 & 24.16 & 31.32 & 37.52 \\
\hline & Boluohu wetland & 2.62 & 5.88 & 9.75 & 12.23 \\
\hline & Dabusu wetland & 0 & 0 & 0 & 0 \\
\hline \multirow[t]{4}{*}{ first } & Nenjiang River artesian connected region & 7.45 & 12.52 & 16.96 & 20.15 \\
\hline & Second Songhua River artesian connected region & 32.58 & 63.82 & 87.52 & 110.52 \\
\hline & Tao'er River artesian connected region & 97.70 & 157.65 & 205.11 & 243.22 \\
\hline & Huolin River artesian connected region & 96.70 & 167.39 & 210.26 & 248.12 \\
\hline \multirow[t]{4}{*}{ second } & Yangshapao Reservoir artesian connected region & 125.05 & 210.14 & 284.67 & 338.30 \\
\hline & Chuangye Reservoir artesian connected region & 7.13 & 12.35 & 15.51 & 18.31 \\
\hline & Huaaopao Lake artesian connected region & 34.53 & 54.75 & 67.98 & 81.35 \\
\hline & HD channel artesian flow connected region & 6.67 & 12.70 & 16.98 & 20.80 \\
\hline \multirow[t]{2}{*}{ third } & Huaaopao Lake artesian connected region & 23.02 & 36.50 & 45.32 & 54.23 \\
\hline & Chuangye Reservoir artesian connected region & 2.02 & 3.49 & 4.39 & 5.18 \\
\hline fourth & Huaaopao Lake lifting connected region & 116.72 & 195.10 & 270.26 & 323.34 \\
\hline \multirow[t]{2}{*}{ fifth } & Huaaopao Lake lifting connected region & 95.17 & 159.08 & 220.37 & 263.65 \\
\hline & Yangshapao Reservoir water lifting connected region & 24.37 & 40.95 & 55.47 & 65.93 \\
\hline \multicolumn{2}{|l|}{ total } & 988.34 & 1239.00 & 1671.52 & 2004.89 \\
\hline \multicolumn{2}{|c|}{ Suitable ecological water requirement } & 422.29 & 1375.69 & 2130.94 & 2701.22 \\
\hline \multicolumn{2}{|c|}{ Maximum ecological water requirement } & 1410.63 & 2614.69 & 3802.46 & 4706.11 \\
\hline
\end{tabular}


Overall, results from this study demonstrate that the minimum ecological water requirement in WJL was $174.13,771.74,1250.60,1602.06$ million $\mathrm{m}^{3}$ under the precipitation guarantee rate of $25 \%, 50 \%, 75 \%, 90 \%$, respectively. The suitable ecological water requirement in WJL was 422.29, 1375.69, 2130.94, 2701.22 million $\mathrm{m}^{3}$ under the precipitation guarantee rate of $25 \%, 50 \%, 75 \%, 90 \%$, respectively. The maximum ecological water requirement in WJL was 1410.63, 2614.69, 3802.46, 4706.11 million $\mathrm{m}^{3}$ under the precipitation guarantee rate of $25 \%, 50 \%, 75 \%, 90 \%$, respectively. Among the wetlands being studied, 54\% were identified as priorities for water supply, first grade was about 24\%. Among the first grade of suitable ecological water requirements, the Tao'er River artesian connected region accounted for about 39\%, and Huolin River artesian connected region accounted for about $41 \%$. The critical sources of water supply to most lakes and marsh wetlands were Tao'er River and Huolin River. Currently, water supplies from these two rivers are rapidly decreasing; this poses a significant risk to the ecological function of the wetlands in WJL.

\section{Conclusion}

This study proposed and tested a method for determining the hydrological connectivity and grades of water supply requirements by wetlands in WJL. The ecological water requirement of wetlands in WJL can be classified into three categories: minimum, suitable, maximum. In a hydrological connectivity analysis, WJL was found to consist of 12 hydrological connected regions. Twelve indicators were selected to establish the evaluation index system of wetlands water supply grading in WJL, and 6 grades were determined. The minimum ecological water requirement in WJL was $1.74 \times 10^{8}, 7.72 \times 10^{8}, 12.51 \times 10^{8}, 16.02 \times 10^{8} \mathrm{~m}^{3}$ with precipitation guarantee rate of $25 \%$, $50 \%, 75 \%, 90 \%$, respectively. The suitable ecological water requirement in WJL was $4.22 \times 10^{8}, 13.76 \times 10^{8}, 21.31 \times 10^{8}, 27.01 \times 10^{8} \mathrm{~m}^{3}$ with precipitation guarantee rate of $25 \%$, $50 \%, 75 \%, 90 \%$, respectively. The maximum ecological water requirement in WJL was $14.11 \times 10^{8}, 26.15 \times 10^{8}, 38.02 \times 10^{8}, 47.06 \times 10^{8} \mathrm{~m}^{3}$. Effective utilization of flood water, as a resource, was found to be essential for supplying water to sustain the lakes and marsh wetlands in WJL.

Acknowledgements. This study was supported by the Scientific Research Project of Public Welfare Industry of the Ministry of Water Resources, China (No.201401014), National Natural Science Foundation of China (Grant No. 41301086 and No. 41371108). Mrs Muriel Vaughan at Edith Cowan University is thanked for revising English spellings and grammar.

\section{REFERENCE}

[1] Bracken, L.J., Wainwright, J., Ali, G.A., Tetzlaff, D., Smith, M.W., Reaney, S.M., Roy, A.G. (2013): Concepts of hydrological connectivity: Research approaches, pathways and future agendas. - Earth-Science Reviews 119: 17-34. 
[2] Dong, J.W., Yang, J.Y., Yang, W.P., Zhang, S.J. (2014): Eco-environmental issues related to river-lake connection in western part of Jilin Province. - China Water Resources 22: 26-30.(in Chinese)

[3] Jilin Daily. (2015): West Jilin Province's "River and Lake Connectivity" Describes a Beautiful Scene of Thriving Fishery and Animal Husbandry and Exuberant Grass and Abundant Grains. http://english.jl.gov.cn/News/GeneralNews/201504/t20150414_ 1974448. html. Accessed 10 April 2015.

[4] Li, F., Zhang, S.W., Bu, K., Yang, J.C., Wang, Q., Chang, L.P. (2015): The relationships between land use change and demographic dynamics in western Jilin province. - Journal of Geographical Sciences 25(5): 617-636.

[5] Li, L.J., Li, J.Y., Liang, L.Q., Liu, Y.M. (2009): Method for calculating ecological water storage and ecological water requirement of marsh. - Journal of Geographical Sciences 19: 427-436.

[6] Freeman, M.C., Pringle, C.M., Jackson, C.R. (2007): Hydrologic connectivity and the contribution of stream headwaters to ecological integrity at regional scales. - JAWRA Journal of the American Water Resources Association 43(1): 5-14.

[7] Herath, G. (2004): Incorporating community objectives in improved wetland management: the use of the analytic hierarchy process. - Journal of Environmental Management 70(3): 263-273.

[8] Jang, H.J., Lee, G.G. (2013): A Study on National Wetland Evaluation for the Selection of Priority Control Target Wetlands in South Korea. - KSCE Journal of Civil Engineering 17(7): 1603-1613.

[9] Lesschen, J.P., Schoor, J.M., Cammeraat, L.H. (2009): Modelling runoff and erosion for a semi-arid catchment using a multi-scale approach based on hydrological connectivity. Geomorphology 109: 174-183.

[10] Lexartza-Artza, I., Wainwright. J. (2009): Hydrological Connectivity: Linking Concepts with Practical Implications. - Catena 79: 146-152.

[11] Li, Y.Y., Li, Z.L., Huang, H.J., Wang, Z.G., Chen, M. (2014): Analyzing the Evolution of the Interconnected River System Network and Driving Factors. - Resources Science 36(6): 1152-1157.(in Chinese)

[12] Luo, W., Grudzinski, B., Pederson, D. (2011): Estimating hydraulic conductivity for the Martian subsurface based on drainage patterns - A case study in the Mare Tyrrhenum Quadrangle. - Geomorphology 125: 414-420.

[13] Pan, X.L., Zhang, D.Y., Quan L. (2006): Interactive factors leading to dying-off Carex tato in Momoge wetland polluted by crude oil, Western Jilin, China. - Chemosphere 65: 1772-1777.

[14] Ren, C.Y., Zhang, B., Wang, Z.M., Song, K.S., Liu, D.W., Liu, Z.M. (2007): A GIS-based Tupu Analysis of Dynamics of Saline-alkali Land in Western Jilin Province. - Chinese Geographical Science 17(4): 333-340.

[15] Saaty, T.L. (1980): The Analytic Hierarchy Process. - McGraw Hill, New York.

[16] Sheng, Q., Shen, S.H., Gu, Z. (2007): Conversion Coefficient between Small Evaporation Pan and Theoretically Calculated Water Surface Evaporation in China. -Journal of Nanjing Institute of Meteorology 30(4): 561-565.

[17] Shore, M., Murphy, P.N.C., Jordan, P., Mellander, P-E., Kelly-Quinn, M., Cushen, M., Mechan, S., Shine, O., Melland, A.R. (2013): Evaluation of a surface hydrological connectivity index in agricultural catchments. - Environmental Modelling \& Software 47: 7-15. 
[18] Tang, Y., Wang, H., Yan, D.H. (2005): Wetland Ecological Water Demand in Xianghai Natural Reserve. - Resources Science 27(5): 101-106.

[19] Wang, X.L., Ning, L.M., Hu, W.B. (2003): Application of analytic hierarchy process to assessing the ecological vulnerability of wetlands in the Jianghan plain. - Chinese Geographical Science 13(3): 272-276.

[20] Wang, Y.F., Zhong, Y.S., Cui, W.H., Lv, P. (2010): Flood inundation and disaster prediction based on DEM. - 2010 Second IITA International Conference on Geoscience and Remote Sensing, 54-57.

[21] Wang, Z.Q., Zhang, B., Yu, L., Zhang, S.Q., Wang, Z.M. (2006): Study on LUCC and the ecological security response of wetlands in Western Jilin Province. - Arid Zone Research 23(3): 419-426.

[22] Yue, S.P., Zhang, S.W., Yan, Y.C. (2008): Analysis of wetland landscape pattern change and its driving mechanism in Jilin western part. - China Environmental Science 28(2): 163-167.(in Chinese)

[23] Zang, C., Zou, Q.T., Ma, J.X. (2014): Vulnerability analysis of regional interconnected river system network and its applications. - Water Resources \& Power 32(9): 28-31.(in Chinese)

[24] Zhang, G.X., Zhang, L., Fan, W., Feng, X.Q., Dong, L.Q. (2014): Wetland ecohydrology and water resource management.- Beijing: science press.

[25] Zhang, R.Q., Zhang, X.D., Yang, J.Y., Yuan, H. (2013): Wetland ecosystem stability evaluation by using Analytical Hierarchy Process (AHP) approach in Yinchuan Plain, China. - Mathematical and Computer Modelling 57(3-4): 366-374. 